\title{
Macronutrient extraction curves of the onion crop
}

\section{Curvas de extração de macronutrientes pela cultura da cebola}

\author{
Felipe Augusto Reis Gonçalves ${ }^{1}$; Priscila Maria de Aquino²; Luiz Otávio Duarte ${ }^{3 *}$; \\ Rosiane Filomena Batista Almeida de Aquino4; Marcelo Rodrigues dos Reis ${ }^{5}$; \\ Leonardo Angelo de Aquino 5
}

\begin{abstract}
This study aimed to determine the extraction curves and accumulation order of macronutrients of two onion cultivars. In commercial fields in the region of Alto Paranaíba, MG, Brazil, onion plants of the cultivars 'Optima' and 'Sirius' were collected during the cycle in 2014 and 2015 to determine dry matter and macronutrient accumulation. The yield was determined at harvest time. Three phases of dry matter and nutrient accumulations were observed. The first phase had a slow accumulation and was followed by a fast increment and subsequent stabilization in phases two and three, respectively, for most of the nutrients in both cultivars and years of cultivation. Duration and accumulated at each phase were different between cultivars and years of cultivation. The total and commercial bulb yield did not vary between cultivars but only between years of cultivation, with average values of 117 and $60 \mathrm{Mg} \mathrm{ha}^{-1}$ in 2014 and 2015, respectively. The partitioning of dry matter and macronutrients followed the same model for both cultivars and years of cultivation. Macronutrients with the largest partitioning for bulbs are $\mathrm{P}$ and $\mathrm{S}$. The decreasing extraction order for both cultivars was $\mathrm{K}>\mathrm{Ca}>\mathrm{N}>\mathrm{P}>\mathrm{Mg}>\mathrm{S}$ in 2014 and $\mathrm{K}>\mathrm{N}>\mathrm{Ca}>\mathrm{P}>\mathrm{S}>\mathrm{Mg}$ in 2015 .
\end{abstract}

Key words: Nutrient accumulation. Allium cepa. Harvest index. Plant nutrition. Uptake rates.

\section{Resumo}

Objetivou-se determinar as curvas de extração e a ordem de acúmulo de macronutrientes de dois cultivares de cebola. Em cultivos comerciais na região do Alto Paranaíba - MG, plantas de cebola das cultivares 'Optima' e 'Sirius' foram coletadas durante o ciclo, nos anos de 2014 e 2015, para determinação do acúmulo de matéria seca e macronutrientes. A produtividade foi determinada na colheita. Observaramse três fases nos acúmulos de matéria seca e nutrientes: uma primeira, de acúmulo lento, foi seguida por incremento rápido e posterior estabilização nas fases dois e três, respectivamente, para maioria dos nutrientes em ambas cultivares e anos de cultivo. A duração das fases e o acumulado em cada uma foram distintos entre as cultivares e anos de cultivo. A produtividade total e comercial de bulbos não variou entre as cultivares, apenas entre os anos de cultivo, obtendo-se média de 117 e $60 \mathrm{Mg} \mathrm{ha}^{-1}$, nos anos de 2014 e 2015, respectivamente. A partição de matéria seca e macronutrientes pela cebola seguiu o mesmo

1 M.e em Agronomia, Produção Vegetal, Instituto de Ciências Agrárias, Universidade Federal de Viçosa, Campus de Rio Paranaíba, UFV/CRP, Rio Paranaíba, MG, Brasil. E-mail: felipe.a.agro@gmail.com

2 M.e em Agronomia - Ciência do Solo, Departamento de Solos, Universidade Federal de Viçosa, UFV, Viçosa, MG, Brasil. E-mail: aquino.agronomia@gmail.com

3 Discente de Doutorado em Agronomia - Produção Vegetal, Departamento de Produção Vegetal, Universidade Estadual Paulista, Faculdade de Ciências Agrárias e Veterinárias, FCAV/UNESP, Jaboticabal, SP, Brasil. E-mail: luizotavioduarte@folha.com.br

4 Diretora, Instituto de Pesquisa Agrícola do Cerrado, IPACER, Rio Paranaíba, MG, Brasil. E-mail: rosiane.aquino@yahoo.com.br

5 Profs., Assistente, Instituto de Ciências Agrárias, Universidade Federal de Viçosa, Campus de Rio Paranaíba, UFV/CRP, Rio Paranaíba, MG, Brasil. E-mail: reisagro@gmail.com

* Author for correspondence 
modelo para ambas cultivares e anos de cultivo. Os macronutrientes com maior partição para os bulbos são o $\mathrm{P}$ e o S. A ordem decrescente de extração, para ambas cultivares, foi $\mathrm{K}>\mathrm{Ca}>\mathrm{N}>\mathrm{P}>\mathrm{Mg}>\mathrm{S}$ em 2014, e $\mathrm{K}>\mathrm{N}>\mathrm{Ca}>\mathrm{P}>\mathrm{S}>\mathrm{Mg}$ em 2015.

Palavras-chave: Acúmulo de nutrientes. Allium cepa. Índice de colheita. Nutrição de plantas. Taxas de absorção.

\section{Introduction}

Onion is one of the main commercial species of the family Alliaceae. In 2015, about 56 thousand hectares of onion were grown in Brazil, with a production that surpassed 1.5 million tons and an average yield of $26.8 \mathrm{Mg} \mathrm{ha}^{-1}$ (ANUÁRIO BRASILEIRO DE HORTALIÇAS, 2016).

Onion has a high nutritional demand and is highly demanding in fertilizers. The rational use of inputs is an essential practice in modern agriculture, not being different from fertilization. Controversies can be found between fertilization recommendations in the "5a Aproximação" (RIBEIRO et al., 1999) and "Boletim Técnico 100" (TRANI et al., 1997) with those carried out by farmers, who tend to apply higher doses than those recommended. High doses in relation to demand can generate a nutritional imbalance and thus contribute to a reduction of nutrient recovery efficiency and the waste of fertilizers (ZHANG et al., 2010).

Adequate nutrition of the onion crop influences several factors, such as increased yield and sanity and bulb quality. Excessive fertilization, mainly of $\mathrm{N}, \mathrm{P}$, and $\mathrm{K}$, monoculture, and indiscriminate use of acidity correctors are common practices in producing regions of this vegetable (KURTZ; ERNANI, 2010). Fertilizer programs should define the amount of nutrients to be replenished in the soil since the quantities exported by bulbs represent a significant component (MAY et al., 2008).

The study of the nutritional crop demand is essential in order to recommend adequate fertilizer doses to reduce losses in the system and optimize yield (SINGH et al., 2012). The cycle of most vegetable crops is short, with a high demand for nutrients concentrated in a short period. Therefore, in this group of plants, the knowledge of extraction and accumulation of nutrients in different phenological stages of the crop is essential (CASTOLDI et al., 2009).

The extraction curve associated with nutrient recovery efficiency by the crop indicates the nutritional need of the plant (CASTOLDI et al., 2009). Once the nutrient uptake curve is defined, the fertilizer doses are adjusted according to crop management, soil type, fertilizer source, climate conditions, among others. Thus, extraction curves provide information of paramount importance for efficient management of fertilizers in a crop. Nutrient extraction curves allow us to know the phenological stages in which each nutrient is most required. Thus, it is possible to plan more rational cultivation activities, potentiating the recommended dose and the ideal phenological stage for fertilizer application (BENDER et al., 2013). In addition, quantifying the partitioning of nutrients in plant organs allows estimating the export and return of nutrients to the soil after harvest.

Therefore, this study aimed to characterize the accumulation and partitioning of dry matter and macronutrients, as well as generate the order of nutrient extraction by the onion cultivars 'Optima' and 'Sirius'.

\section{Material and Methods}

Samplings of the onion cultivars 'Optima' and 'Sirius' were carried out in commercial areas located in Rio Paranaíba, MG, in 2014 and 2015. According to the Köppen-Geiger classification, the predominant climate in the region is Cwa, 
characterized by a dry season and a well-defined precipitation during collection periods are shown in rainy season. The values of relative humidity, Figure 1.

minimum temperature, maximum temperature, and

Figure 1. Relative humidity, minimum and maximum temperatures, and precipitation recorded in the area in 2014 (A) and 2015 (B) during the collection period.
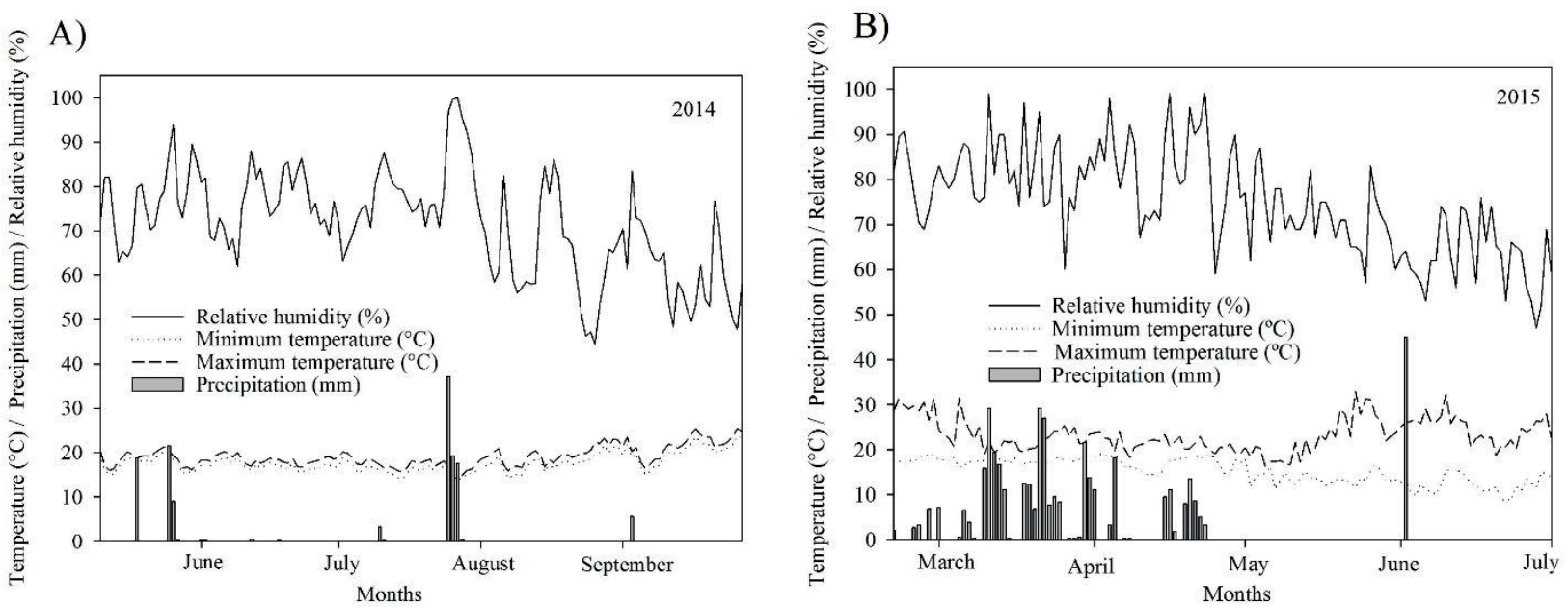

In the first year, the cultivated areas were at an altitude of $860 \mathrm{~m}$, while in the second year the and 'Optima' at $1140 \mathrm{~m}$ of altitude. Before sowing, soil chemical analysis was performed (Table 1).

Table 1. Soil chemical analysis of the areas of onion cultivation with the cultivars 'Optima' and 'Sirius' in 2014 and 2015 in Rio Paranaíba, MG, Brazil.

\begin{tabular}{|c|c|c|c|c|c|}
\hline \multirow{2}{*}{ Attribute } & \multirow{2}{*}{ Unit } & \multicolumn{2}{|c|}{2014} & \multicolumn{2}{|c|}{2015} \\
\hline & & 'Optima' & 'Sirius' & 'Optima' & 'Sirius' \\
\hline $\mathrm{pH}$ & ----- & 5.5 & 5.5 & 5.6 & 5.7 \\
\hline Organic matter & $\mathrm{g} \mathrm{dm}^{-3}$ & 23.0 & 24.0 & 24.0 & 35.0 \\
\hline $\mathrm{P}$ - remaining & $\operatorname{mg~L} L^{-1}$ & 21.9 & 15.9 & 16.7 & 3.4 \\
\hline $\mathrm{P}$ & $\mathrm{mg} \mathrm{dm}^{-3}$ & 22.3 & 20.1 & 62.3 & 6.7 \\
\hline $\mathrm{K}^{+}$ & $\mathrm{mmol}_{\mathrm{c}} \mathrm{dm}^{-3}$ & 4.8 & 4.6 & 2.1 & 3.9 \\
\hline $\mathrm{Ca}^{2+}$ & $\mathrm{mmol}_{\mathrm{c}} \mathrm{dm}^{-3}$ & 24.0 & 24.0 & 29.0 & 24.0 \\
\hline $\mathrm{Mg}^{2+}$ & $\mathrm{mmol}_{\mathrm{c}} \mathrm{dm}^{-3}$ & 8.0 & 9.0 & 9.0 & 9.0 \\
\hline $\mathrm{S}$ & $\mathrm{mg} \mathrm{dm}^{-3}$ & 33.0 & 25.0 & 17.0 & 14.0 \\
\hline $\mathrm{CEC}(\mathrm{T})$ & $\mathrm{mmol}_{\mathrm{c}} \mathrm{dm}^{-3}$ & 97.3 & 96.6 & 94.2 & 71.8 \\
\hline Base saturation (V) & $\%$ & 38.0 & 39.0 & 63.0 & 51.0 \\
\hline Potential acidity $(\mathrm{H}+\mathrm{Al})$ & $\mathrm{mmol}_{\mathrm{c}} \mathrm{dm}^{-3}$ & 60.5 & 59.0 & 53.0 & 35.0 \\
\hline
\end{tabular}

Extractors: $\mathrm{P}, \mathrm{K}, \mathrm{Cu}, \mathrm{Fe}, \mathrm{Mn}$, and $\mathrm{Zn}-$ Mehlich-1; $\mathrm{Ca}^{2+}, \mathrm{Mg}^{2+}$, and $\mathrm{Al}^{3+}-1 \mathrm{~mol} \mathrm{~L}{ }^{-1} \mathrm{KCl}$; $\mathrm{B}$ - hot water. 
In 2014, both cultivars were sown with a population of 1.3 million seeds per hectare. The fertilization during cultivation consisted of $230 \mathrm{~kg}$ $\mathrm{ha}^{-1}$ of $\mathrm{N}, 900 \mathrm{~kg} \mathrm{ha}^{-1}$ of $\mathrm{P}_{2} \mathrm{O}_{5}, 410 \mathrm{~kg} \mathrm{ha}^{-1}$ of $\mathrm{K}_{2} \mathrm{O}$, $2 \mathrm{~kg} \mathrm{ha}^{-1}$ of $\mathrm{B}, 2.6 \mathrm{~kg} \mathrm{ha}^{-1}$ of $\mathrm{Cu}$ and $\mathrm{Zn}$, and $150 \mathrm{~g}$ $\mathrm{ha}^{-1}$ of Mo (Mo was applied via leaf). The cultivar 'Optima' was harvested at 131 days after sowing (DAS) and 'Sirius' at 140 DAS.

In the following year, the fertilization of the cultivar 'Sirius' consisted of $212 \mathrm{~kg} \mathrm{ha}^{-1}$ of N, 1,182 $\mathrm{kg} \mathrm{ha}^{-1}$ of $\mathrm{P}_{2} \mathrm{O}_{5}, 318 \mathrm{~kg} \mathrm{ha}^{-1}$ of $\mathrm{K}_{2} \mathrm{O}, 2.6 \mathrm{~kg} \mathrm{ha}^{-1}$ of B and $\mathrm{Cu}$, and $7.8 \mathrm{~kg} \mathrm{ha}^{-1}$ of $\mathrm{Zn}$. The cultivar 'Optima' was fertilized with $158 \mathrm{~kg} \mathrm{ha}^{-1}$ of $\mathrm{N}, 755 \mathrm{~kg} \mathrm{ha}^{-1}$ of $\mathrm{P}_{2} \mathrm{O}_{5}, 458 \mathrm{~kg} \mathrm{ha}^{-1}$ of $\mathrm{K}_{2} \mathrm{O}, 1 \mathrm{~kg} \mathrm{ha}^{-1}$ of $\mathrm{B}$ and $\mathrm{Cu}$, and $3 \mathrm{~kg} \mathrm{ha}^{-1}$ of $\mathrm{Zn}$. For both cultivars, $200 \mathrm{~g} \mathrm{ha}^{-1}$ of $\mathrm{B}, 150 \mathrm{~g} \mathrm{ha}^{-1} \mathrm{Cu}$ and $\mathrm{Zn}, 400 \mathrm{~g} \mathrm{ha}^{-1}$ of $\mathrm{Mn}$, and $150 \mathrm{~g} \mathrm{ha}^{-1}$ of Mo were applied via leaf. In this year of cultivation, both cultivars were harvested at 131 DAS.

Weed management was carried out with the herbicide flumioxazin in the different areas and planting seasons, with two sequential applications and two manual weeding. Fungicides and insecticides were applied according to the need of control visualized in the field.

Four georeferenced points were demarcated in each sampled plot. Plants were sampled in a radius of $20 \mathrm{~m}$ around these points. This procedure was adopted to reduce the variability effect of soil fertility on the determination of the curve of nutrient extraction and dry matter yield. During collection, sampling was carried out on both sides and internal and external rows of the crop in the beds. At each sampling point, plants were collected in $2 \mathrm{~m}$ of double rows. The period between collections and the number of samplings varied according to crop development.

In 2014, samplings were performed at the 4th, 5th, 7th, and 9th leaf stages (leaf emission stage) and when plants had at least $50 \%$ of bulbs in the commercial classes II (diameter of 35-50 mm), III (diameter of 50-70 cm), IV (diameter of 70-90 cm), and at the harvest point. In the cultivar 'Optima', these phenological stages occurred at $62,69,86,93$, $101,109,127$, and 131 DAS. In the cultivar 'Sirius', it corresponded to $69,93,101,109,127,135$, and 140 DAS. In addition, for the cultivar 'Sirius', the extraction data at the 5th leaf stage were not presented due to the loss of samples in the drying process.

In 2015, samplings were performed at the 4th, 8th, and 10th leaf stages and when plants had at least $50 \%$ of bulbs in the commercial classes II, III, IV, and at the harvest point. For the cultivar 'Optima', collection stages corresponded to $62,86,93,101$, 109, 127, and 131 DAS, while the cultivar 'Sirius' was collected at $62,86,93,101,109,127$, and 131 DAS.

Bulb and leaf samples were washed in running water and dried in a forced air circulation oven at 70 ${ }^{\circ} \mathrm{C}$ for $72 \mathrm{~h}$. After drying, the material was weighed to determine the dry matter in each part of the plant. Bulbs and leaves were ground in a Willey mill. N, $\mathrm{P}, \mathrm{K}, \mathrm{Ca}, \mathrm{Mg}$, and $\mathrm{S}$ contents of plant tissues were determined according to Malavolta et al. (1997).

Yield $\left(\mathrm{Mg} \mathrm{ha}^{-1}\right)$ was estimated by collecting all the plants present in $10 \mathrm{~m}$ of bed, in four replications, at the georeferenced points, with the total yield referring to all bulbs and commercial yield referring to bulbs distributed in the classes II, III, and IV. Nutrient accumulation was calculated by multiplying the dry matter production by the nutrient contents in the plant tissue. Extraction curves were generated by plotting the accumulation of dry matter and nutrients in the shoot, bulb, and total (leaves plus bulb) as a function of the phenological stage, represented by collection dates, for each nutrient. Nutrient relative extraction $(\mathrm{kg}$ $\mathrm{Mg}^{-1}$ ) was calculated from the division of the total accumulated in the whole plant at harvest time by the total relative yield. The harvest index (\%) was obtained by the ratio between the dry matter accumulation of the nutrient in the bulb and the total accumulation of the crop. 
The data were submitted to analysis with the use of descriptive statistics. The dry matter accumulation curve and nutrient extraction curves were fit using the software Sigma Plot Version 11. Models with the highest coefficient of determination and statistical significance were considered valid with $\mathrm{p} \leq 0.05$. Thus, the models that best fit were linear, quadratic, and logistic, which is shown below:

$\hat{\mathrm{y}}=\frac{\mathrm{L}}{1+\mathrm{e}^{-\mathrm{k}\left(\mathrm{x}-\mathrm{x}_{0}\right)}}$, where:

$\hat{\mathrm{y}}=$ dependent variable;

$\mathrm{L}=$ maximum value of the curve;

$\mathrm{e}=$ basis of the natural logarithms (Euler number);

$\mathrm{k}=$ slope of the curve;

$\mathrm{x}=$ independent variable (days after sowing, DAS);

$\mathrm{x}_{0}=$ value of $\mathrm{x}$ at the midpoint of the sigmoid curve.

The determination of the maximum values estimated for all response variables was performed as a function of the maximum $\mathrm{X}$ for each case, i.e. through the value referring to the harvest date of each cultivar and year.

\section{Results and Discussion}

Leaf (LDM) and bulb dry matter (BDM) accumulations presented three phases. The number of days and magnitude of accumulation at each phase varied in the two years for both cultivars (Figures 2A, B, C, and D). Both cultivars accumulated little dry matter in the first growth phase, both leaf and bulb, in both years of cultivation. The threshold of this growth phase for the subsequent phase was 69 and 80 DAS for the cultivar 'Optima' and 'Sirius', respectively, in relation to LDM. For BDM, this phase lasted up to 93 DAS for the cultivar 'Optima' and up to 101 DAS for the cultivar 'Sirius'. For this last cultivar, this phase was possibly extended due to its longer cycle.
In a study with the cultivar 'Optima' under notillage, Pôrto et al. (2006) observed similar results for dry matter accumulation. The growth model fit by these authors was characterized by three phases of dry matter accumulation. Two cultivars of onion grown in Rio Grande do Norte presented a curve of shoot dry matter accumulation that extended its first phase up to 83 days after transplanting (AGUIAR NETO et al., 2014). Method and planting season, genotype difference, and climate conditions may have provided this difference. In addition to genotype, edaphoclimatic factors have an influence on the phenotypic expression of the plant. In fact, there was a difference in the extension of the first growth phase in the second year of cultivation. For LDM, it was 58 and 64 DAS and for BDM it was up to 76 and 98 DAS for the cultivars 'Optima' and 'Sirius', respectively.

The highest dry matter increment occurred in the second growth phase for both cultivars and years of cultivation (Figures 2A, B, C, and D). In the leaf, in the first year, the cultivar 'Optima' accumulated $2,958 \mathrm{~kg} \mathrm{ha}^{-1}$ of LDM from 69 to 93 DAS and the cultivar 'Sirius' accumulated $3,358 \mathrm{~kg} \mathrm{ha}^{-1}$ of LDM from 69 to 109 DAS, corresponding to $98 \%$ of the total. In the second year, the second phase lasted until 101 and 103 DAS for the cultivars 'Optima' and 'Sirius', respectively. The highest accumulation rate of BDM in 2014 for the cultivar 'Optima' occurred from 93 to 107 DAS, totaling $9,312 \mathrm{~kg}$ $\mathrm{ha}^{-1}$, which corresponded to $80.6 \%$ of the total accumulated up to the end of the cycle. The cultivar 'Sirius' presented an accumulation of $10,431 \mathrm{~kg}$ $\mathrm{ha}^{-1}$ in the period from 101 to 118 DAS. In 2015, the highest accumulation rate for both cultivars occurred between 76 and 101 DAS, which resulted in a total of 2,533 and 3,060 kg ha ${ }^{-1}$ for the cultivars 'Optima' and 'Sirius', respectively.

The third phase was characterized by a lower accumulation rate in relation to the second phase (Figure 2A, B, C, and D). In 2014, this phase lasted for 20 (107 to 127 DAS) and 22 days (118 to 140 DAS) for the cultivars 'Optima' and 'Sirius', 
respectively. In this phase, a reduction was observed in the LDM and BDM accumulation, reaching a near standstill as it approaches the harvest when the bulb begins the maturation stage. In 2015, after the stability period of the second phase, a final phase of increase was observed in BDM until the end of the cycle, with $43 \%$ of the total accumulated for the cultivar 'Optima' from 101 to 121 DAS and $65 \%$ of the total accumulated for the cultivar 'Sirius' from 103 to 124 DAS.

Figure 2. Curves of dry matter accumulation in the leaves $(\bullet)$, bulbs $(\circ)$, and whole plant $(\boldsymbol{\nabla})$ of the onion cultivars 'Optima' (A and C) and 'Sirius' (B and D) in 2014 (A and B) and 2015 (C and D).
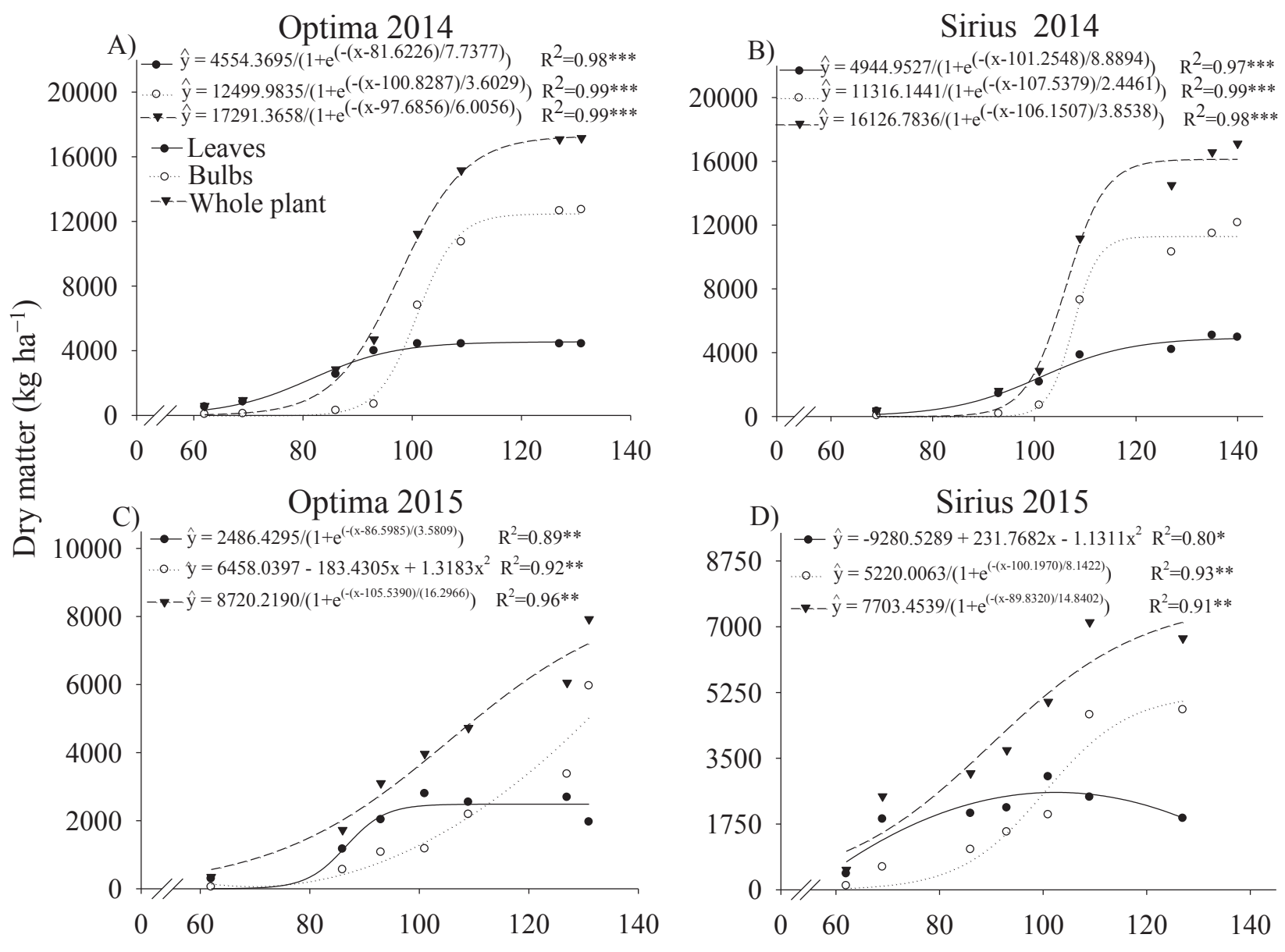

Days after sowing

The estimated maximum accumulation of the total dry matter on the harvest day was 17,224 and $7,209 \mathrm{~kg} \mathrm{ha}^{-1}$ for the cultivar 'Optima' in 2014 and 2015 , respectively, and 16,124 and $7,251 \mathrm{~kg} \mathrm{ha}^{-1}$ for 'Sirius' in 2014 and 2015, respectively. The lowest harvest index (71\%) was estimated for the cultivar 'Sirius' in 2014 and the highest (75.3\%) for the cultivar 'Optima' in 2015 (Table 2). This reinforces that climate changes, even if small, can interact with genotypes differently. 
Table 2. Harvest index (\%), relative extraction of dry matter and macronutrients, and yield for the onion cultivars 'Optima' and 'Sirius' in 2014 and 2015 in Rio Paranaíba, MG, Brazil.

\begin{tabular}{|c|c|c|c|c|}
\hline \multirow{2}{*}{ Variable } & \multicolumn{2}{|c|}{2014} & \multicolumn{2}{|c|}{2015} \\
\hline & 'Optima' & 'Sirius' & 'Optima' & 'Sirius' \\
\hline & \multicolumn{4}{|c|}{ Harvest index $(\%)$} \\
\hline Dry matter & 74.2 & 71.0 & 75.3 & 71.6 \\
\hline $\mathrm{N}$ & 71.5 & 62.6 & 69.8 & 66.3 \\
\hline $\mathrm{P}$ & 83.4 & 78.1 & 71.3 & 70.4 \\
\hline $\mathrm{K}$ & 63.2 & 64.6 & 61.9 & 58.0 \\
\hline $\mathrm{Ca}$ & 61.2 & 55.7 & 46.8 & 37.2 \\
\hline $\mathrm{Mg}$ & 69.0 & 60.1 & 66.7 & 50.0 \\
\hline \multirow[t]{2}{*}{$\mathrm{S}$} & 62.2 & 72.3 & 71.4 & 72.7 \\
\hline & \multicolumn{4}{|c|}{ Relative extraction $\left(\mathrm{kg} \mathrm{Mg}^{-1}\right)$} \\
\hline $\mathrm{N}$ & 1.67 & 1.34 & 1.55 & 1.32 \\
\hline $\mathrm{P}$ & 0.71 & 0.68 & 0.38 & 0.49 \\
\hline $\mathrm{K}$ & 2.68 & 2.39 & 2.11 & 1.95 \\
\hline $\mathrm{Ca}$ & 1.66 & 1.66 & 0.75 & 0.78 \\
\hline $\mathrm{Mg}$ & 0.46 & 0.40 & 0.22 & 0.23 \\
\hline \multirow[t]{2}{*}{$\mathrm{S}$} & 0.27 & 0.29 & 0.32 & 0.37 \\
\hline & \multicolumn{4}{|c|}{ Yield $\left(\mathrm{Mg} \mathrm{ha}^{-1}\right)$} \\
\hline Total & 118.2 & 115.8 & 59.0 & 60.7 \\
\hline Commercial & 101.1 & 102.5 & 59.0 & 60.1 \\
\hline
\end{tabular}

The sigmoidal model explained the total accumulation (shoot and bulb) of nutrients by the onion. $\mathrm{N}$ was the second most accumulated nutrient, with a mean of $198 \mathrm{~kg} \mathrm{ha}^{-1}$ for both cultivars in 2014 and $80 \mathrm{~kg} \mathrm{ha}^{-1}$ in 2015 (Figures 3A, B, C, and D). Vidigal et al. (2010) also found that $\mathrm{N}$ was the second most accumulated macronutrient. However, a difference was observed between the LDM and BDM accumulation in periods of higher demand. In the leaf, the period between 85 to 105 DAS required the highest $\mathrm{N}$ content for the cultivar 'Optima' and between 85 and 115 DAS for 'Sirius' in 2014 (Figure 3A).

In 2015, $\mathrm{N}$ accumulation in the leaf stabilized after 80 DAS for the cultivar 'Optima' and after 65 DAS for the cultivar 'Sirius' (Figures $3 \mathrm{C}$ and D). In the bulb, the demand was increasing for the cultivar 'Optima' from 90 DAS, while for the cultivar
'Sirius' a phase of a rapid increase was observed between 90 and 110 DAS, followed by stabilization. Bulb presented an $\mathrm{N}$ accumulation higher than that observed for leaf at the end of the cycle, which can be attributed to an $\mathrm{N}$ redistribution from the shoot (source) to the bulb (drain).

$\mathrm{P}$ was the fourth most accumulated nutrient, with a mean of 81 and $26 \mathrm{~kg} \mathrm{ha}^{-1}$ for both cultivars in 2014 and 2015, respectively (Figures 4A, B, C, and D). The period of highest accumulation for this nutrient was from 82 to 105 DAS and from 67 DAS for the cultivar 'Optima' in 2014 and 2015, respectively (Figures 4A and C). For the cultivar 'Sirius', the highest accumulation occurred from 80 DAS in both years (Figures 4B and D). However, this nutrient presented the highest harvest index in 2014, showing that most of $\mathrm{P}$ in the whole plant is in the bulb. P participation in the bulb was approximately 
$81 \%$ (Table 2). As for N, P has its leaf increment practically null after 110 DAS. In the bulb, on the contrary, the accumulation was continuous until the harvest.

Figure 3. Curves of nitrogen accumulation in the leaves $(\bullet)$, bulbs $(\circ)$, and whole plant $(\boldsymbol{\nabla})$ of the onion cultivars 'Optima' (A and C) and 'Sirius' (B and D) in 2014 (A and B) and 2015 (C and D).

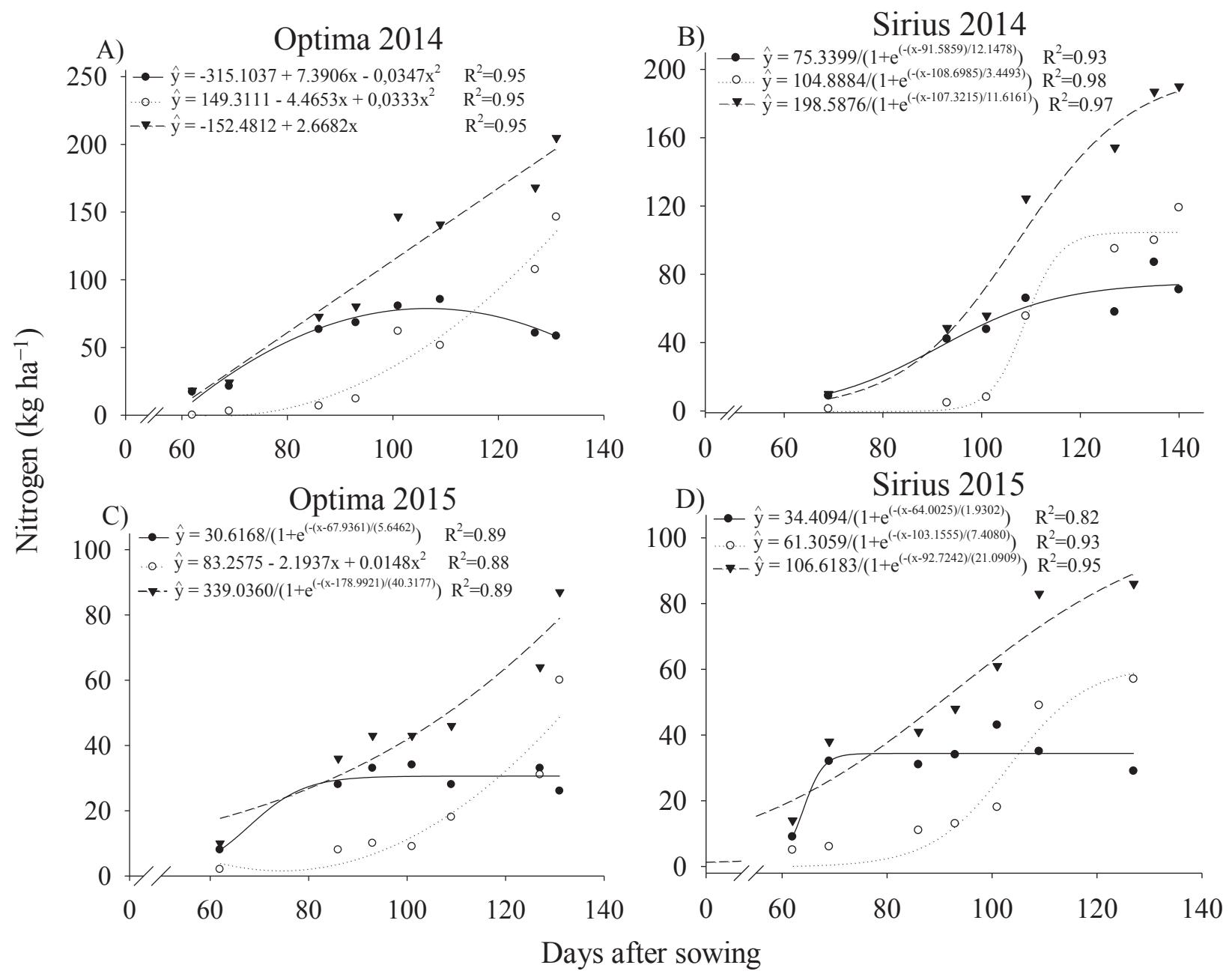

Despite the low P extraction by onion plants, fertilization with this nutrient is high, with a mean of $935 \mathrm{~kg} \mathrm{ha}^{-1}$ of $\mathrm{P}_{2} \mathrm{O}_{5}$ in both years of cultivation. In addition to the high buffering power and low $\mathrm{P}$ availability in the studied soils (Table 1), the extraction curves of this nutrient showed that the highest demand generally occurs from the middle third to the end of the cycle, mainly for bulb accumulation (Figures 4A, B, C, and D). Because all $\mathrm{P}$ is applied at planting and at the beginning of the cycle the plants have few roots when plants are at a full demand the majority had already been fixed by iron and aluminum oxyhydroxides (NOVAIS et al., 2007). Given this, it would be interesting to seek strategies to apply $\mathrm{P}$ as topdressing fertilization during periods of high demand, which would optimize its application and could even reduce the applied dose. $\mathrm{P}$ is considered slightly mobile in the soil (NOVAIS et al., 2007) and the topdressing application should be carried out near the root system, with the use of fertirrigation and subsurface drip system, for example. 
Figure 4. Curves of phosphorus accumulation in the leaves $(\bullet)$, bulbs $(\circ)$, and whole plant $(\boldsymbol{\nabla})$ of the onion cultivars 'Optima' (A and C) and 'Sirius' (B and D) in 2014 (A and B) and 2015 (C and D).

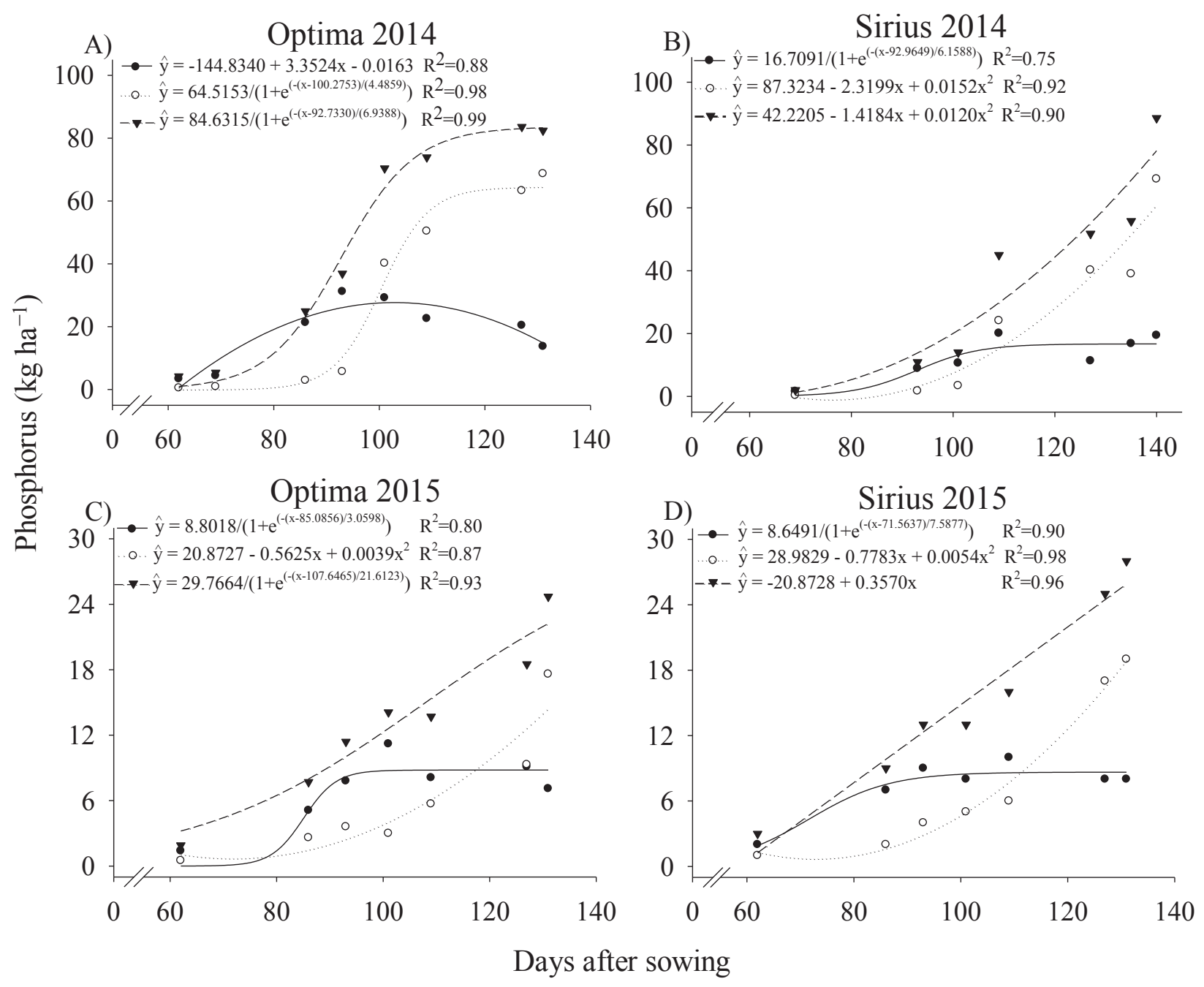

$\mathrm{K}$ was the nutrient accumulated in higher The period of highest demand for $\mathrm{K}$ in 2014 was amounts by onion. The harvest index of $\mathrm{K}$ was $63.2 \%$ (2014) and $61.9 \%$ (2015) for the cultivar 'Optima', and 64.6\% (2014) and 58\% (2015) for the cultivar 'Sirius' (Table 2). Vidigal et al. (2010) also observed that $\mathrm{K}$ was the nutrient most extracted by onion. This fact is explained by its osmotic function and transport of photoassimilates from leaves to reserve organs (MALAVOLTA, 2006), the bulb in the case of onion. 81 to 122 DAS and 85 to 115 DAS for the cultivars 'Optima' and 'Sirius', respectively (Figures 5A and B). In this period, accumulation was equivalent to 81 and $89.8 \%$ of the total accumulated at the end of the cycle for the cultivars 'Optima' and 'Sirius', respectively. The cultivar 'Sirius' presented the highest mean accumulation rate of $\mathrm{K}$ in the period of higher demand, with an accumulation of $8.27 \mathrm{~kg}$ $\mathrm{ha}^{-1}$ per day, demonstrating that this cultivar is more demanding on $\mathrm{K}$ when compared to 'Optima'. 
Figure 5. Curves of potassium accumulation in the leaves $(\bullet)$, bulbs $(\circ)$, and whole plant $(\boldsymbol{\nabla})$ of the onion cultivars 'Optima' (A and C) and 'Sirius' (B and D) in 2014 (A and B) and 2015 (C and D).
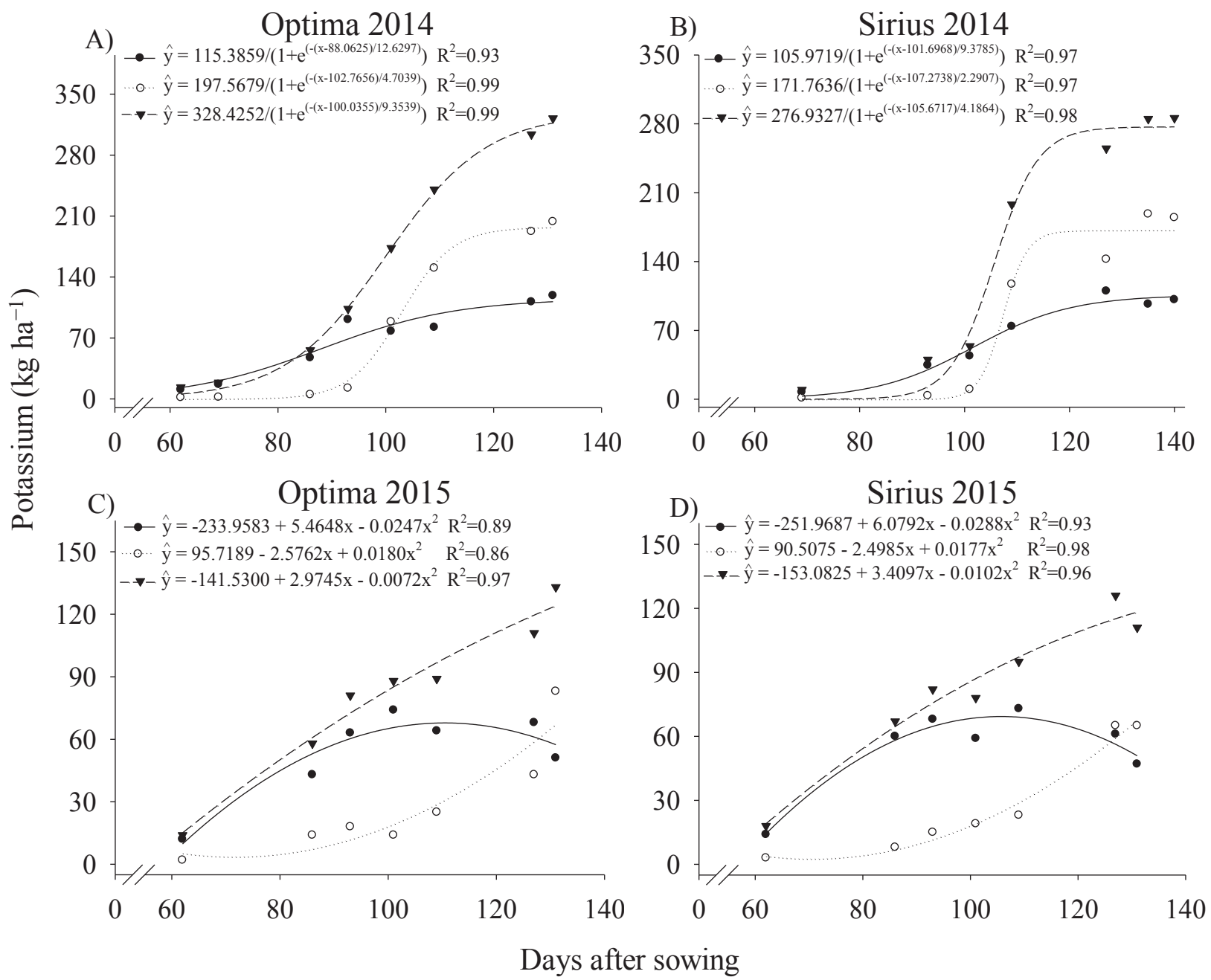

Ca was the third most accumulated nutrient by the plant, with 194 and $46 \mathrm{~kg} \mathrm{ha}^{-1}$ at the end of the cycle for both cultivars in the first and second years of cultivation, respectively. The content of this nutrient in soil is similar for both years and cultivation areas (Table 1). However, the relative extraction of $\mathrm{Ca}\left(1.66 \mathrm{~kg} \mathrm{Mg}^{-1}\right)$ and total yield (117 $\left.\mathrm{Mg} \mathrm{ha}^{-1}\right)$ in 2014 represented practically twice that observed in the following year $\left(0.76 \mathrm{~kg} \mathrm{Mg}^{-1}\right.$ and $60 \mathrm{Mg} \mathrm{ha}^{-1}$ ) (Table 2). Lower precipitation and hence lower cloudiness, higher mean temperature, and lower relative humidity (Figure 1A) may have contributed to higher evapotranspiration and higher photosynthesis conditions, which would justify the higher $\mathrm{Ca}$ accumulation and yield in 2014 .

The highest $\mathrm{Ca}$ accumulations occurred between 70 and 105 DAS and 85 and 117 DAS for the cultivar 'Optima' in 2014 and 2015, respectively (Figures 6A and C), and between 85 and 115 DAS and 70 and 100 DAS for the cultivar 'Sirius' in 2014 and 2015, respectively (Figures 6B and D), which corresponded to $47 \%$ of the total in the whole plant. Vidigal et al. (2010) observed similar results, in which $\mathrm{Ca}$ was the third nutrient most accumulated by the whole plant, with an estimated value of 97.7 $\mathrm{kg} \mathrm{ha}^{-1}$. 
The shoot accumulated a higher amount of $\mathrm{Ca}$ in the second year (Figures 6C and D), different from that observed for N, P, and $\mathrm{K}$ at the end of the cycle. The cultivar 'Sirius' had a harvest index of $46 \%$ for $\mathrm{Ca}$ in the mean of two years. The low mobility of $\mathrm{Ca}$ in the plants may lead to its insignificant redistribution (MALAVOLTA, 2006). Moreover, according to Malavolta et al. (1997), the competition in $\mathrm{Ca}$ and $\mathrm{K}$ uptake decreases $\mathrm{Ca}$ concentration in the bulb when there is a higher $\mathrm{K}$ flow to this organ.

Figure 6. Curves of calcium accumulation in the leaves $(\bullet)$, bulbs $(\circ)$, and whole plant $(\boldsymbol{\nabla})$ of the onion cultivars 'Optima' (A and C) and 'Sirius' (B and D) in 2014 (A and B) and 2015 (C and D).
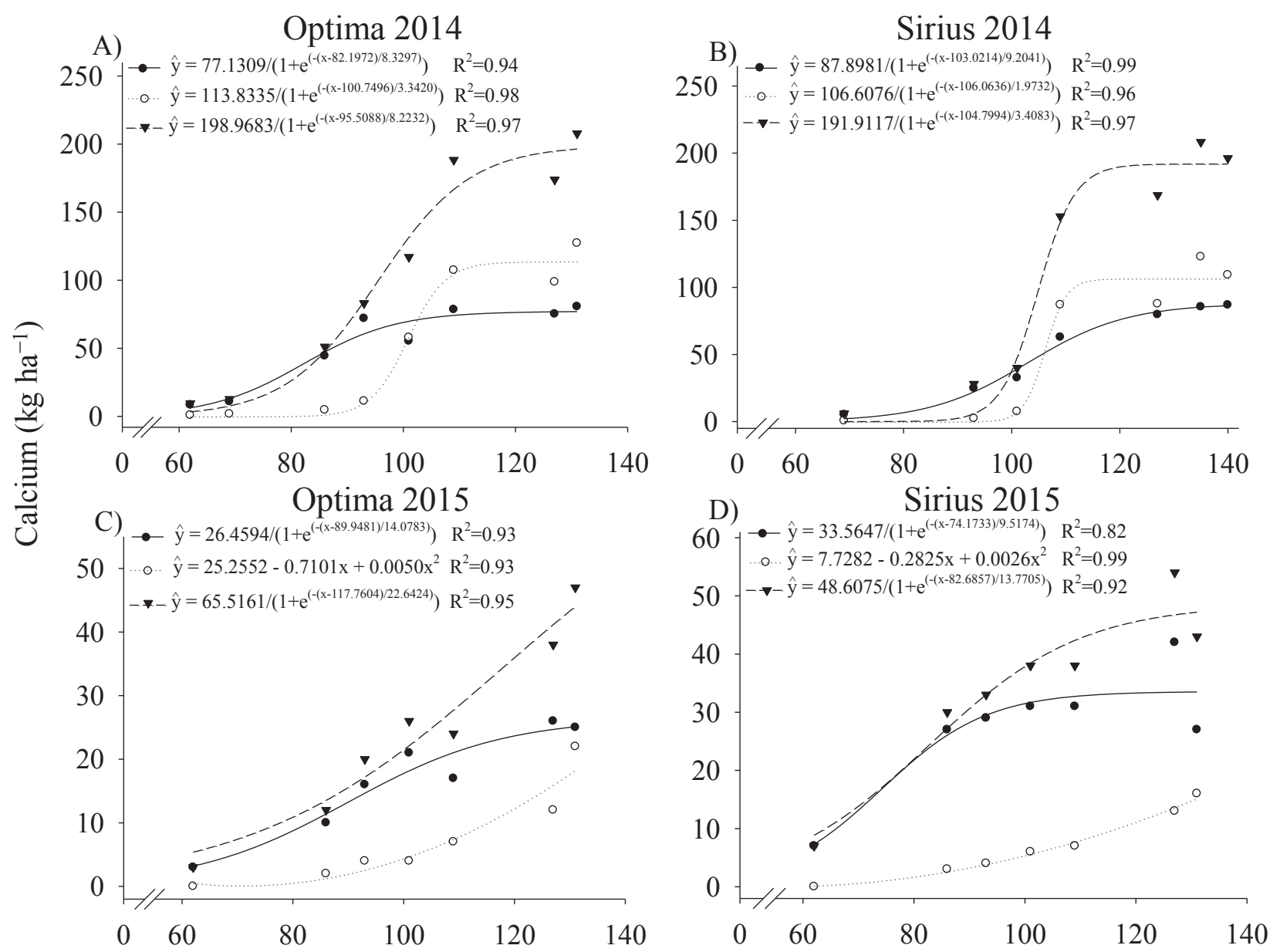

Days after sowing

Similar to $\mathrm{Ca}$, leaf accumulated a similar amount of $\mathrm{Mg}$ as the bulb did for the cultivar 'Sirius' in 2015 (Figure 7D). Leaf presented a higher accumulation in the period of 75 to 95 DAS for the cultivar 'Optima' in 2014 and 2015, respectively. For the cultivar 'Sirius', the highest accumulation was verified between 62 and 98 DAS in both years of cultivation.
The bulb showed a higher $\mathrm{Mg}$ accumulation from 105 and 82 DAS for the cultivars 'Optima' and 'Sirius', respectively.

$\mathrm{S}$ presented the highest demand from 80 DAS in both cultivars and years of cultivation (Figures $8 \mathrm{~A}$, $\mathrm{B}, \mathrm{C}$, and D). For the cultivar 'Optima', this period was shorter, i.e. only 30 days (Figures $8 \mathrm{~A}$ and 
C). Similar to N, P, and K and different from that observed for $\mathrm{Ca}$ and $\mathrm{Mg}, \mathrm{S}$ accumulation was higher in the bulb, with a value of about $66.2 \%$ for the cultivar 'Optima' and $72.5 \%$ for the cultivar 'Sirius' in both years. Similar results were found by Nasreen et al. (2003), who verified that $\mathrm{S}$ accumulates more in the bulb, with a value of about $82 \%$. These authors explain that $\mathrm{S}$ accumulation occurs in the bulb as the plant reaches a more photosynthetic development.
With an adequate leaf growth, a good translocation and photoassimilate partitioning occur from leaves to the bulbs, resulting in larger bulb size and higher dry matter production. This high $\mathrm{S}$ translocation to the bulbs at the last growth stage is due to a high concentration of sulfur amino acids, which give the characteristic aroma and flavor (LEE et al., 2003; MALAVOLTA, 2007).

Figure 7. Curves of magnesium accumulation in the leaves $(\bullet)$, bulbs $(\circ)$, and whole plant $(\boldsymbol{\nabla})$ of the onion cultivars 'Optima' (A and C) and 'Sirius' (B and D) in 2014 (A and B) and 2015 (C and D).
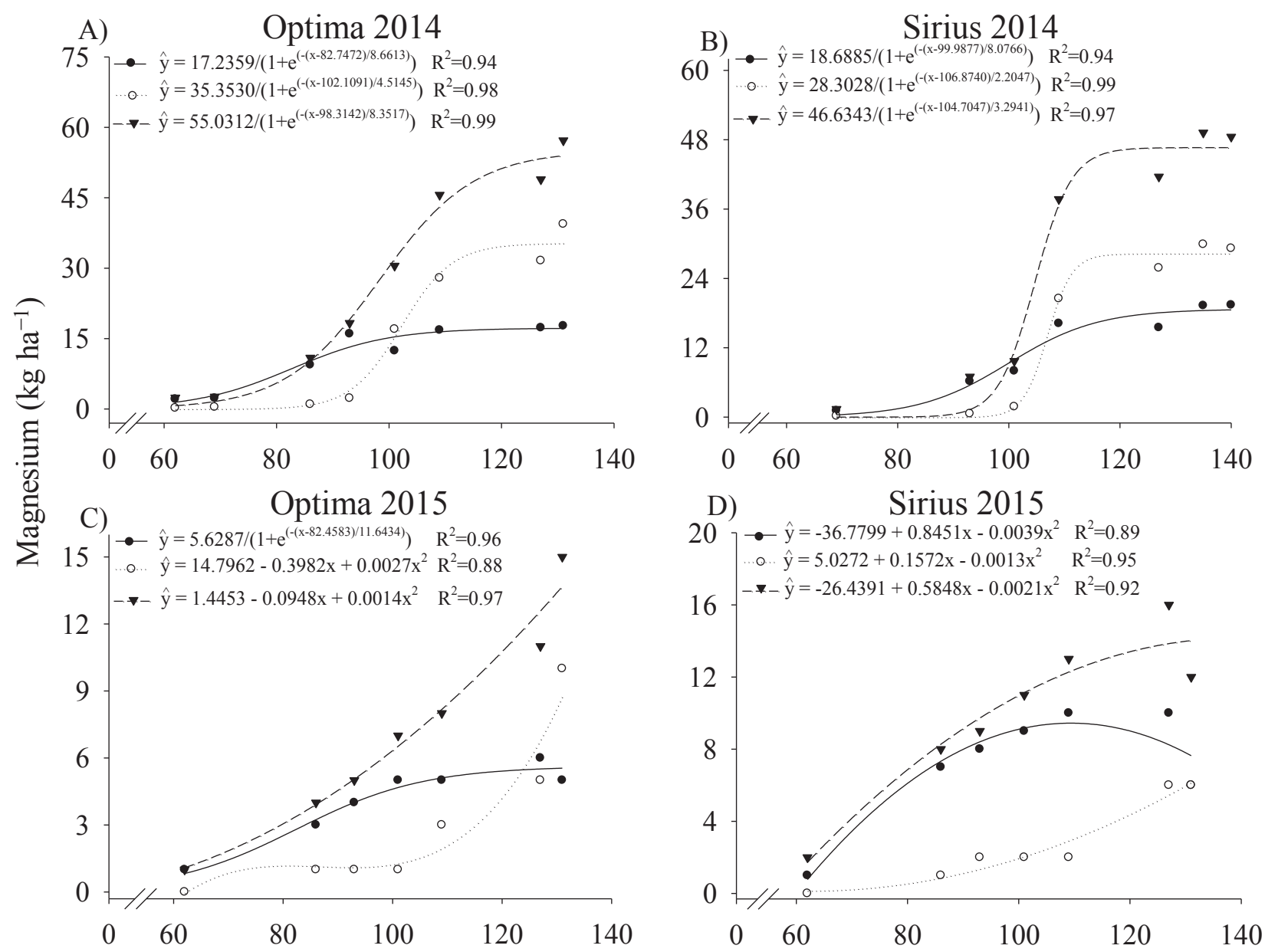

Days after sowing

Based on the relative extraction, $\mathrm{N}$ and $\mathrm{K}$ were the most extracted nutrients under the most studied conditions, except for the cultivar 'Sirius' in 2014, in which $\mathrm{Ca}$ was more extracted when compared to N. They also presented a high harvest index, with a mean of years and cultivars of 68 and $62 \%$ 
for $\mathrm{N}$ and $\mathrm{K}$, respectively (Table 2). Due to this high demand, they represent a high production cost since their applications must be divided, thus increasing workforce and operational costs. From the extraction curves, it is possible to estimate the productive potential of the cultivars 'Optima' and 'Sirius' and thus determine more rational and exact doses of $\mathrm{N}$ and $\mathrm{K}$, as well as determine the number of topdressing applications required.

The mean total and commercial yield did not vary as a function of the cultivars, but as a function of the years of cultivation, with a mean of 117 and $60 \mathrm{Mg} \mathrm{ha}^{-1}$ in 2014 and 2015, respectively (Table 2 ). Moreover, the mean of discard was $13 \%$ in 2014 in relation to the total yield and almost null in the subsequent year. Climate factors may have contributed to this difference between the years of cultivation. During the cycle of 2014, the relative humidity and precipitation were lower when compared to 2015 (Figure 1B). Therefore, lower precipitation, lower cloudiness, and higher solar irradiation led to a higher onion yield in 2014 .

Figure 8. Curves of sulfur accumulation in the leaves $(\bullet)$, bulbs $(\circ)$, and whole plant $(\boldsymbol{\nabla})$ of the onion cultivars 'Optima' (A and C) and 'Sirius' (B and D) in 2014 (A and B) and 2015 (C and D).

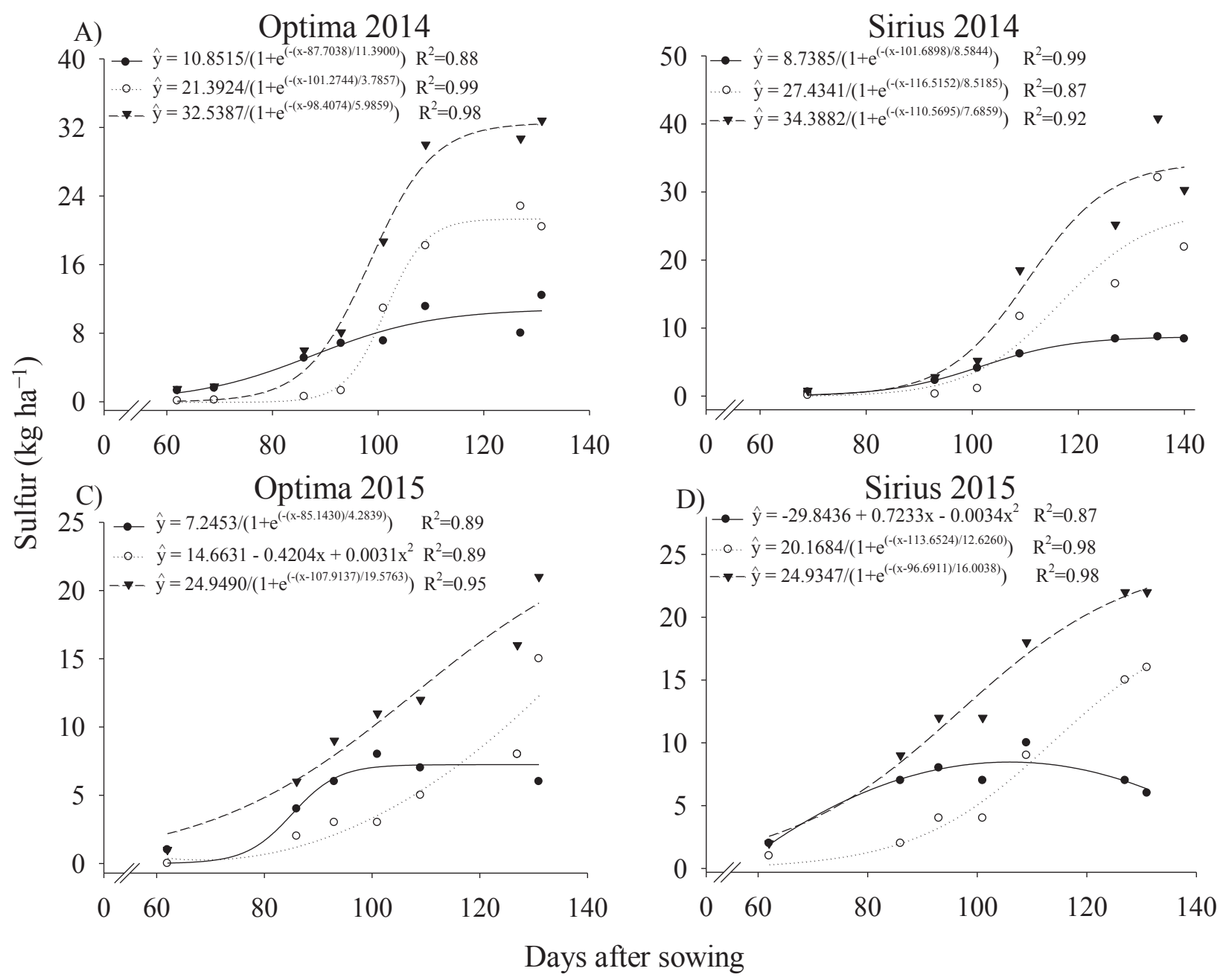


The assessment of the amount of macronutrients accumulated by onion bulbs established by direct seeding should be used to calibrate the amount of nutrients to be replenished by means of fertilization programs since it represents an important component of nutrient removal from the soil. Influence of cultivar and cultivation conditions were observed on the nutrient extraction curves for the onion crop in Alto Paranaíba, MG, Brazil. Thus, the fertilization of this crop must consider the demand of different cultivars, as well as the conditions of cultivation, which can influence their productive potential.

\section{Conclusions}

Dry matter and macronutrient accumulation were characterized by three phases: the first phase had a slow accumulation and was followed by a fast increment and subsequent stabilization. The macronutrients most accumulated in the bulbs are $\mathrm{P}$ and S, followed by $\mathrm{K}$ and $\mathrm{N}$. The decreasing order of nutrient accumulation observed for the onion cultivars 'Optima' and 'Sirius' was $\mathrm{K}>\mathrm{N}>\mathrm{Ca}>$ $\mathrm{P}>\mathrm{Mg}>\mathrm{S}$ and $\mathrm{K}>\mathrm{Ca}>\mathrm{N}>\mathrm{P}>\mathrm{Mg}>\mathrm{S}$ in 2014, respectively, and $\mathrm{K}>\mathrm{N}>\mathrm{Ca}>\mathrm{P}>\mathrm{S}>\mathrm{Mg}$ for both cultivars in 2015.

\section{Acknowledgments}

To DSc Angélica Plata for assistance in writing this research, with criticisms and suggestions. To the National Council for Scientific and Technological Development (CNPq), Coordination for the Improvement of Higher Education Personnel (CAPES), and Minas Gerais Research Foundation (FAPEMIG) for granting the scholarships and financial support. To Agristar and Institute of Agricultural Research of the Cerrado (IPACER) for financing this research.

\section{References}

AGUIAR NETO, P. A.; GRANGEIRO, L. C.; MENDES, A. M. S.; COSTA, N. D.; MARROCOS, S. T. P.; SOUSA, V. F. L. Crescimento e acúmulo de macronutrientes na cultura da cebola em Baraúna (RN) e Petrolina (PE). Revista Brasileira de Engenharia Agrícola e Ambiental, Campina Grande, v. 18, n. 4, p. 370-380, 2014. DOI: 10.1590/0100-2945-192/13

ANUÁRIO BRASILEIRO DE HORTALIÇAS. Brazilian vegetable yearbook. Santa Cruz do Sul: Gazeta, 2016. 42 p.

BENDER, R. R.; HAEGELE, J. W.; RUFFO, M. L.; BELOW, F. E. Nutrient uptake, partitioning, and remobilization in modern, transgenic insect-protected maize hybrids. Agronomy Journal, Madison, v. 105, n. 1, p. 161-170, 2013. DOI: 10.2134/agronj2012.0352

CASTOLDI, R.; CHARLO, H. C. D. O.; VARGAS, P. F; BRAZ, L. T. Crescimento, acúmulo de nutrientes e produtividade da cultura da couve-flor. Horticultura Brasileira, Vitória da Conquista, v. 27, n. 4, p. 438-446, 2009. DOI: $10.1590 / \mathrm{S} 0102-05362009000400007$

KURTZ, C.; ERNANI, P. R. Produtividade de cebola influenciada pela aplicação de micronutrientes. Revista Brasileira de Ciência do Solo, Viçosa, v. 34, n. 1, p. 133142, 2010. DOI: 10.1590/S0100-06832010000100014

LEE, S. N.; KIM, N. S.; LEE, D. S. Comparative study of extraction techniques for determination of garlic flavor components by gas chromatography-mass spectrometry. Analytical and Bioanalytical Chemistry, Teerã, v. 377, n. 4, p. 749-756, 2003. DOI: 10.1007/s00216-003-2163-Z

MALAVOLTA, E. Manual de nutrição mineral de plantas. São Paulo: Agronômica Ceres, 2006. 631 p.

MALAVOLTA, E.; MORAES, M. F. Fundamentos do nitrogênio e do enxofre na nutrição mineral das plantas cultivadas. In: YAMADA, T.; ABDALA, S. R. S.; VITTI, G. C. (Ed.). Nitrogênio e enxofre na agricultura brasileira. Piracicaba: POTAFÓS, 2007. p. 189-249.

MALAVOLTA, E.; VITTI, G. C.; OLIVEIRA, S. A. Avaliação do estado nutricional das plantas: princípios e aplicações. 2. ed. Piracicaba: POTAFOS, 1997. 319 p.

MAY, A.; CECÍlIO FILHO, A. B.; PORTO, D. R. Q.; VARGAS, P. F.; BARBOSA, J. C. Acúmulo de macronutrientes por duas cultivares de cebola produzidas em sistema de semeadura direta. Bragantia, Campinas, v. 67, n. 2, p. 507-512, 2008. DOI: 10.1590/S000687052008000200027 
NASREEN, S.; HAQ, S.; HOSSAIN, M. Sulphur effects on growth responses and yield of onion. Asian Journal of Plant Sciences, Lucknow, v.2, n. 12, p. 897-902, 2003. DOI: 10.3923/ajps.2003.897.902

NOVAIS, R. F.; SMYTH, T. J.; NUNES, F. N. Fósforo. In: NOVAIS, R. F.; ALVAREZ V., V. H.; BARROS, N. F.; FONTES, R. L. F.; CANTARUTTI, R. B.; NEVES, J. C. L. (Ed.). Fertilidade do solo. Viçosa, MG: Sociedade Brasileira de Ciência do Solo, 2007. p. 471-550.

PÔRTO, D. R. Q.; CECÍLIO FILHO, A. B.; MAY, A.; BARBOSA, J.C.Acúmulo de macronutrientes pela cebola 'Optima' estabelecida por semeadura direta. Horticultura Brasileira, Vitória da Conquista, v. 24, n. 4, p. 470-475, 2006. DOI: 10.1590/S0102-05362006000400015

RIBEIRO, A. C.; GUIMARÃES, P. T. G.; ALVAREZ V., V. H. Recomendações para o uso de corretivos $e$ fertilizantes em Minas Gerais: $5^{\text {a }}$ aproximação. Viçosa: CFSEMG, 1999. 322 p.

SINGH, D. P.; BELOY, J.; MCINERNEY, J. K.; DAY, L. Impact of boron, calcium and genetic factors on vitamin $\mathrm{C}$, carotenoids, phenolic acids, anthocyanins and antioxidant capacity of carrots (Daucus carota L.). Food Chemistry, Reading, v. 132, n. 3, p. 1161-1170, 2012. DOI: 10.1016/j.foodchem.2011.11.045

TRANI, P. E.; PASSOS, F. A.; TAVARES, M.;AZEVEDO FILHO, J. A. Beterraba, cenoura, nabo, rabanete e salsa. In: RAIJ, B. van; CANTARELLA, H.; QUAGGIO, J. A.; FURLANI, M. C. (Ed.). Recomendações de adubação e calagem para o Estado de São Paulo: Campinas: IAC, 1997. p. 174-176. (Boletim técnico, 100).

VIDIGAL, S. M.; MOREIRA, M. A.; PEREIRA, P. R. G. Crescimento e absorção de nutrientes pela planta cebola cultivada no verão por semeadura direta e por transplantio de mudas. Bioscience Journal, Uberlândia, v. 26, n. 1 , p. $59-70,2010$.

ZHANG, F.; NIU, J.; ZHANG, W.; CHEN, X.; LI, C.; YUAN, L.; XIE, J. Potassium nutrition of crops under varied regimes of nitrogen supply. Plant and Soil, Wageningen, v. 335, n.1-2, p. 21-34, 2010. DOI: $10.1007 /$ s11104-010-0323-4 
